\title{
Tactical Deductions from the Course of Practice of the Swiss Field Artillery in 1890
}

\section{Lonsdale Hale, Colonel A. Schumacher \& Lieutenat Colonel Walford R.A.}

To cite this article: Lonsdale Hale, Colonel A. Schumacher \& Lieutenat Colonel Walford R.A. (1891) Tactical Deductions from the Course of Practice of the Swiss Field Artillery in 1890, Royal United Services Institution. Journal, 35:156, 145-179, DOI: 10.1080/03071849109417265

To link to this article: http://dx.doi.org/10.1080/03071849109417265

\section{Published online: 11 Sep 2009.}

Submit your article to this journal $\llbracket$

Џ Article views: 5

Q View related articles $\sqsubset$ 


\section{FOREIGN SECTION.}

Tirs portion of the Number, hitherto the Occasional Notes, has now become the Foreign Section, and is reserved for articles, either eriginal or compiled, on professional subjects connected with Foreign Ninal and Arilitary matters; also for notices of Professional Books, either Foreign or English.

The Council of the Institution wish that this section shall be dereloped still further, and I have undertakon to continue my Editorship during the current year, with a viow of aiding them in carrying ont this work. It seems to me possible to make this section, and consequently the Journal, tho means of keeping our Members acquainted with all naral and military progress abroad pari passu with that progress; and I shall be glad to receive from members of both Serrices, including in the latter those of the Auxiliary borces, suggestions, information, or offers of assistance.

It is desirable, further, that I slould stats that, as regards editing tho Naral matter in the Section, I shall havo the aid of Naval Oficers, thoroughly competent to give good adrice aud to pronounce sound opiniors.

It must, however, be borne in mind that, as the change from a quarterly to a monthly issue has been made in order to ensure the more prompt publication of the Lactures after their delirery than has hitherto been tho case, the Foreign Section will, as a rule, bo restricted in extent during the Lecture sensou in the first half of the sear, and will be prominent in the second balf.

It is requested that communications and books for roview (the latter under corer to the Librarian) may be addressed to mo at the Royal United Service Institution, Whitehall Yard, London, S.IV.

\section{LONSDALE HALE,}

Colonel ret. R.E.

TACTICAI, DEDUCTIONS FRON TIIF COURSE OF PRACICF OF THE SWISS FIELD AR'TILIERY IN 1890.

By Colonel A. Scnuyscinen, Chief Instructor, Swiss Artillery. Translated by Lieutenant-Colonel Walrond, R.A.

I. Practice, Description of Targets, and Results.

Ir nuay be taken for granted that the Captains who are ordered to attend the course of practice have during the instruction which preceded their appointment fred at least 20 series at the normal targets. 


\section{6}

TACTICAL DEDUCTIONS FROM THE IRACTICE

The course of practice would, therefore, if we except the mere change of practice ground, by no means fulfil its object in the case of such Officers as have alrendy practised at Frauenfeld or Biore, if it offered them only the same problems as are connected with elenentary practice.

Just as the School of Recruits is the place where ordinary details can be thoroughly and correctly learnt, 80 the School of Instruction is that where the practice must be adapted to various conditions and problems; for this reason Majors also are ordered to attend the course, in order that they may learn how the higher grades of practice should be cirried on. Moreover, at the present mornent we are still without certain knowledge as to the value of tactical formations when under artillery tire. The tactical formations of the artillery date also, for the most part, from the days of solid shot, even though we have now in their place shells which give a wide burst, and though there can be no longer any question of the direct hit of a projectile.

While the character of the fire of artillery in former days showed that wide formations were the safest, it would appear as if ridc-bursting shell, especially shrapnel, would warn us to avoid broad formations, and to offeronly a small front to the fire of artillery.

In accordance with the preceding considerations, the programme for the course was founded on the following principles:-

1. Only the first instructional series should be fired at square wooden targets.'

2. For the other series the targets should be such as would be met with on service.

3. As far as possible, all formations which would be uscd in the tactics of the three arms should be cruployed as targets.

4. Each practice, advancing from winor to more complicated problems, should represent some phase of battle, and the targets should be arranged accordingly.

5. The duration of the practice and the number of rounds should be gradually increased.

It was further laid down that in all applied practice the distribution of fire should take place at the commencement of group firing, especially against artillery targets, since, on the one hand, the observation of fire at. this perjod in no way demands a fixed and single objective, while, on the other, prudence forbids us to expose ourselves to the fire of such gins of the enemy as are not under our fire. The theory of the successive destruction of the enemy is derived from the days of solicl shot; it had still some value when common shell was the principal projectile, but has none now when shrapnel are alnost exclusively used.

It must, at the same time, be lere mentioned that the utility and possibility of this rule, which have been doubted by some, have been sufficiently proved; it must, at any rate, be accepted that the distribution of fire must be carried out under some, and, when possible, under an invariable, rube.

The whole course of practice consisted of 66 series; of these, Series 1 to 12 were elementars, Series 64 to 60 kere for indirect fire, while Series 13 to 63, and more especially 21 to 63 , were dedicated to the main question.

The geries were as follows :-

1st Serics. 20th March. At Thun.-Infantry in column of fours (13) are scen; soon after some artillery (14) appears, which is to be silenced; under corer of the fire of the guns, the infantry forms first a column of sections (15), and then procceds to extend groups and supports (16).

1 Oring to an insufficient supply of dummiee, they were used for the third and following series only.

2 'Troops in tro ranks werc inrariably represented bs a single row of dummies. 
Target 13. Column of fours, 40 infantry in fours with 2 paces distance. Range by tangent scale, 2,140 yards. 30 rounds. Time, 11 minutes; interval between rounds, 22 seconds.

14. 3 guns with detachments and teams, limbers at 11 yands interval, following the guns. Range by tangent scale, 1,970 yards. 30 rounds. 'Iime, 12 minutes ; interral between rounds, 24 seconds.

15. 2 ranks of 20 files, standing ; interval, 10 paces. Range, 2,080 yards. 30 rounds. 'Time, 12 minutes; interral between rounds, 24 seconds.

16. 4 groups of skirmishers, each of $10 \mathrm{men}$, kneeling; each group 20 paces wide; 1 man in rear of each group stainding; 100 paces in rear of each of the flank groups a support, consisting of $20 \mathrm{men}$ in one rank. Range to the groups, 1,910 yards; to the supports, 2,000 yards. 30 rounds. Time, 12 minutes ; interval between rounds, 24 sccouds.

2nd Series. 21st Mlarch.: At Thun.-The enemy's artillery (17) has entrenched itself and must be sileuced; in the mean time infantry in column appears (18); some artillery then comes up (19), and is fired on, presumably with success, after which the fire is diverted to the infantry, which has in the mean time extended (20).

17. Emplacements for 3 guns, connected by a slielter-trench; interval between guns, 17 yards; betreen -exch two guns is a limber (without its team) in a trench. The parapet is from 10 to 13 feet thick, and its command is, in front of the gums, 18 inches; in front of the limbers, 3 feet. Range, 1,720 yards. 24 rounds. Time, 13 minutes; interval between rounds, 33 seconds.

18. Target as in 15. Range, 1,970 yards. 24 rounds. Time, 18 ninutes; interval between rounds, 45 seconds.

19. 4 guns with detachments and teams; limber-11 yards in rear of the guns. liange, 2,050 yards. 24 rounds. Time, 12 minutes; interval between rounds, 30 seconds.

20. Turget as in 10. Range to the groups, 1,610 yards; to the supports, 1,750 yards. 24 rounds. Time, 10 minutes; interval between rounds, 25 seconds.

3rd Series. 22nd March. At Thun.-An enemy's battery (21) is to be fired on until an order is received to dircet the fire on a company of infantry, which shows itself in column of sections (22). It is found necessary to again fire on the artillery. (23), which lias in the mean time changed its formation; after this the infantry, which has extended (24), is to be fired on, and finally a column which is advancing on the battery (running target, 25) is to be stopped.

21. 6 guns with detacliments ; interval, 16 yards ; the limbers and teans 11 yards in rear of their guns. Range, 2,190 yards. 214 common shell. Time, 10 minutes; interval between rounds, 25 seconds.

Guns and detachments Limbers and teams

Mean burst of shell, 70 yards short.

22. Four ranks of 20 infantry with 11 paces distauce. Ringe, 2,300 yarrls. 12 common shell and 18 slirapnel. Time, 11 minutes; interval between rounds, 22 seconds.

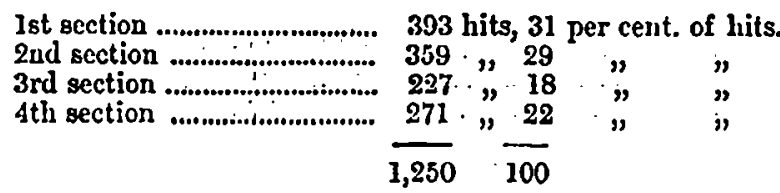


Common sliell burst 77 yaris short.

Shrapnel 82 to 83 yards short; 7 to 9 feet above plane.

23. 6 guns with detachments ; 3 limbers in column of route in rear of each flank; leading limbers 11 yards from the flank-guns; interval of the others, 35 yards. Range, 2,130 yards. 24 common shell. Tinse, 10 minutes; interval between rounds, 25 seconds.

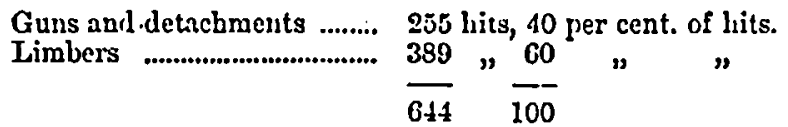

Mean burst of shell, 68 to 70 yards short.

24. The two rear ranks of target No. 22 were posted 55 yards on the flank of the others; the range of the two parts of the target differed by about 22 yards. Shortest range, 2,400 yards. 12 common and 18 shrmpnel. Time, 9 minutes; interval betricen rounds, 18 seconds.

\begin{tabular}{|c|c|c|c|c|c|}
\hline \multirow{4}{*}{ 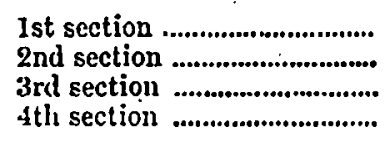 } & \multirow{2}{*}{\multicolumn{2}{|c|}{$\begin{array}{l}1 \text { hit, } \\
9 \text { hits, }\end{array}$}} & \multicolumn{3}{|c|}{1 per cent. of hits. } \\
\hline & & & 7 & ” & \\
\hline & $\mathbf{5 9}$ & " & 44 & $"$ & " \\
\hline & 65 & $"$ & 48 & $"$ & $"$ \\
\hline & & & & & \\
\hline
\end{tabular}

Mean burst of common shell, 80 jards short.

Ditto of shrapnel, 68 yards short; 10 feet above plane.

25. A moving target, 6 feet high and 16 feet wide, in constant movenent on a line slightly oblique to the normal to the front of the battery. Pace, walk. Range, 0,730 to 2,080 yards. 8 common and 16 shapuel. Time, 10 minutes; interval between rounds, 25 seconds.

91 hits.

Mlean burst of common shell, 80 yards short.

Ditto of shrapnel, 67 yards short; 19.5 feet abore plane.

4th Series. 24th Ifarch. At Thun.-Open fire on hostile artillery in emplacements (26). Another battery comes up with its wagons following at 80.yards distance (2i). In the mean time infantry have crept towards the bittery, and suddenly appear (28). When they have been driven off, a liattery in column of route is observed to be approaching the field of battle. The ringe is found on a conspicunus point, and the column is fired on as soon as it reaches that point (29). Finally infantry, who are visible at a distance in double column (30), are dispersed.

20. 'Tirgets as in 17. The guns tire puffs. Range, 1,850 yards. $18 \mathrm{com}$ moni and 12 shrapnel. Time, 9 minutes; interval between rounds, 18 seconds.

51 hits.

Mean burst of common, 55 to 57 yards short.

Ditto of shrapnel, 59 jards short ; 10.5 to 18.5 feet above plane.

27. A battery of 6 guns, with detachments and teams, unlinbered; limleers 11 yards in rear of guns; 6 wagons 80 yards in rear of the limbers; teams facing to thie rear. Range, 1,530 yards. 12 connon and 18 shripmel. Time, 9 minutes; interval between rounds, 18 seconds. .

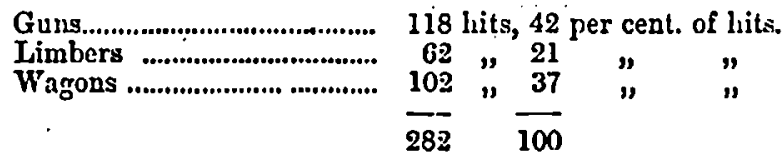


Trean burst of common, 40 yards short.

Ditto of shrapnel, 41 yards short; 12 feet above plane.

28. Four swinging targety' 9 yards long, each representing 10 infantry kneeling : in echelon from the front at 11 yards distance. Range, 380 to ito yards. 12 case shot. Time, 2 minutes; interval between rounds, 10 weconds.

2.t hits.

29. $\Lambda$ pole marks the point on which the guns are to be ranged; two other poles show the limits within which the target is to be fired on. The target consists of 4 small-arm ammunition carts, at a distance of 8 paces, and pulled forward by means of a wire rope. Range, 1,910 yarls. 12 comnon and 12 shrapnel. Time, 12 minutes; interval between rounds, 30 seconds.

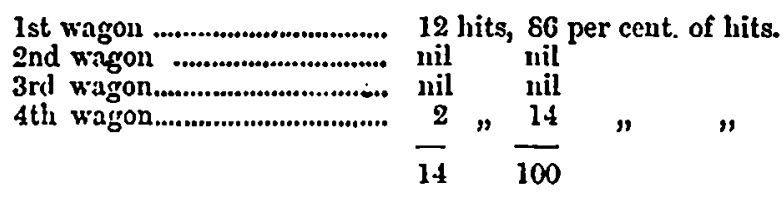

Mean burst of common, $5 \overline{5}$ yards short.

Jitto of shrapuel, 60 yards short; 7\%5 feet alore plane.

30. 320 infantry standing in two parallel columns at 4 paces interval, each column of 8 ranks of 20 men at 10 paces distance. Mange, 2,810 yards. 12 conmon and 12 shrapuel. Tine, 12 minutes; interval between rounds, 30 seconds.

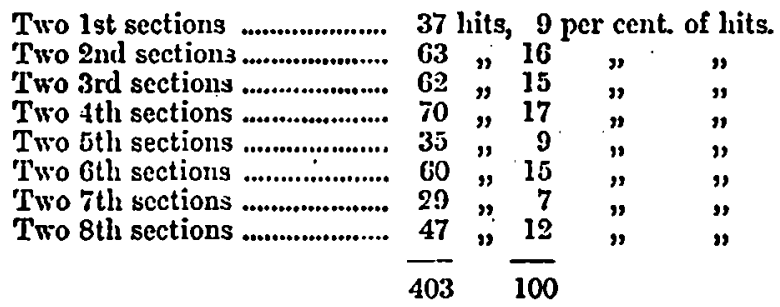

Mean bust of common, 107 yards short.

Ditto of shrapnel, 107 to 112 yards short; 36 to 68.5 feet above plane.

5th Series. $25 t h$ 3larch. At Thten. - Fire is opened on a hostile battery in action (31), of which the wagons stand on either flank at a distance of $\mathbf{3 3 0}$ yards. Under the fire of this battery infantry deploy into a line four deep (32) and open fire; other infantry (33) are advancing in column of fours; the latter are driven back, while the foraner form line of columns (34) and are broken up; a squadron adrancing in colunn of sections (35). is driven back.

31. Sis guns with detachments and teams, unlimbered, the limbers 11 yards in rear of the guns: three wagons on each flank 330 yards in rear of the limbers, in column at 4 paces distance; teams turned to rear. Range to the guns 1,910 yards, to wagons 2,240 yards. 12 common and 18 shrapnel. Time, 11 ninutes; interral between rounds, 22 seconds.

2 These targets aro raised by neans of a weight at the foot. Whon the weight is released by the range-party, tho targets appear.-N. L. W. 


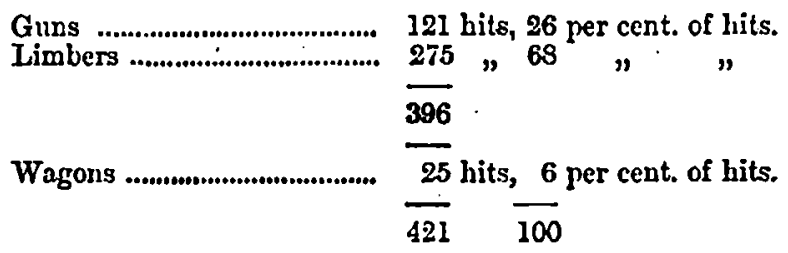

Mean burst of common, 55 yards short.

Ditto of shrapnel, 58 to 70 yards short; 16 to 21 feet above plane.

32. 320 dummies, representing a battalion in line, four deep ; lst and 2 nd ranks, 160 dummies in line knceling; 3rd and 4th rank, 160 dummies standing at 1 yard distance; breadth of the target about 1.45 yards. Small puffs fired in front of the whole of the front rank. . Range, 2,100 yards. 12 common and 12 shrapncl. Time, 10 minutes; interval between rounds, 25 seconds.

Front rank

Rear rank-

0.1 hits, 45 per cent. of hits.

$\frac{116}{210} " \frac{55}{100} "$ "

Mean burst of common, 68 to 70 yards short.

Ditto, of shrapnel, 72 to 74 yards short ; 16 to 23 fect above plane.

33. A company of infantry, 144 men (standing) in column of fours, $36 \mathrm{sec}$ tions of four men with 2 paces distance; the column is on the edge of a rood, descending a hill; difference of level of the first and last files about 160 fect; slope of the hill, 3 over 4 . Range; 2,020 yards. 13 common and 11 shrapnel. Time, 10 minutes ; interval between rounds, 25 seconds.

\begin{tabular}{|c|c|c|c|c|c|c|}
\hline Sections & 1 to $9 \ldots \ldots \ldots \ldots \ldots$ & 209 & lits, & & c & hit \\
\hline ״ & 10 to 18 & 111 & " & 26 & $" 1$ & " \\
\hline " & 19 to 27 & 47 & " & 11 & $"$ & $"$ \\
\hline " & 28 to 36 & 50 & " & 11 & " & " \\
\hline & & 17 & & 0 & & \\
\hline
\end{tabular}

Mean burst of common, 96 yards short.

Ditto of shrapnel, 105 jards short, 33 feet above plane.

3.1. 320 dummies representing infantry standing in 4 columns of sections, each of 4 ranks of 20 men at 10 paces distance; interval between columns 27 yards (half deploying interval). IRange, 2,190 yards; 30 shrapnel.

'Iime, 10 minutes; interval between rounds, 20 seconds.

lat rank

2nd rank

3rd rank

4th rank

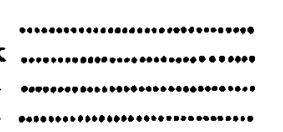

\begin{tabular}{|c|c|c|c|c|}
\hline 343 & hits & 29 & & \\
\hline 294 & " & 25 & " & " \\
\hline $\begin{array}{l}255 \\
302\end{array}$ & " & 21 & $"$ & " \\
\hline & " & 20 & $"$ & " \\
\hline
\end{tabular}

Mlean burst of shrapnel, 77 yards short; $2 \cdot 5$ to 23 feet abore plane.

35. 54 cavalry dumnies in sections of $18 \mathrm{men}$, width 20 yards, in 3 ranks at a distance of 20 yards, visible only through the interval between the columns in target 34 . Range, 2,620 yards.' 30 shrapnel. 'Time' 10 minutes; interval between rounds, 20 seconds. 


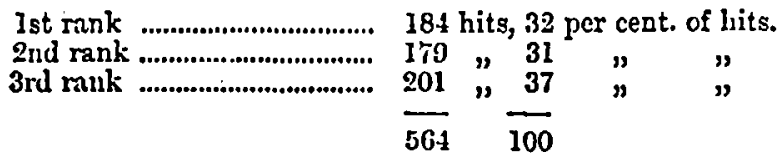

Mean burst of shrapnel, 94 to 96 . yards short; 11.5 to 1.15 feet above plane.

6th Series. 26 th March. At Thun.-A battery in action (30) is silenced, and the fire is then turned on the wagons, which are supposed to be concealed behind a screen (37). In the mean time infantry deploy first into sectioncolumn (38a) and then into groups with supports $(38 b)$; in rear of these is seen a battery advancing in column of sections at full interval (39); this is to be fired on. The practice battery is suddenly charged by cavalry (40); when these have been repulsed, some cavalry which is seen coming up from the back of the practice-ground is fired on (41).

36. 4 guns made of wood bound with iron, which each fire automatically 8 rounds at intervals of 1 minute. In rear are 4 limbers, teams facing to the rear, at 2 distance of 11 jards from the guns. IRange, 2,080 yards. 30 shrnpnel. Time, 8 minutes; interval between rounds, 10 seconds.

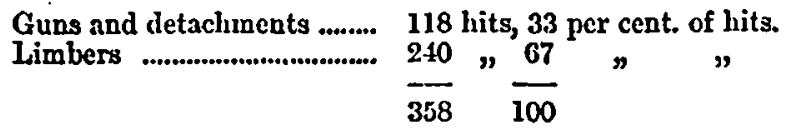

Mean burst of shrapnel, 67 to 68 yards short; 14 to 16.5 feet above plane.

37. 110 gards to the rear and 82 yards to the left of the above battery is a wall of earth 22 yards long; in front of this wall is a hedge, made of firbranches, 33 yards long and about 6 feet high; close in rear of the wall stand the 4 wagons of the battery with 5 yards interval, teams facing to rear. Range, about 2,190 yards. 24 common shell. Time, 8 minutes ; interval between rounds, 20 seconds.

142 hits.

Mean burst of common, 69 yards short.

$38 a$. Column of sections, 4 ranks of $20 \mathrm{men}$, standing, with 10 paces listance. Range, 2,130 yards. 24 shrapnel. Time, 10 minutes; interval between rounds, 25 seconds.

38b. 4 groups of 10 shirmishers each, kneeling, 110 yards in front of $38 a$; breadth of groups about 16 yards. In the intervals between 1 and 2 , and 3 and 4, groups, and partly in rear of them, are two supports, each of 20 men, knecling; 55 yards in rear of each flank are 20 men, standing. Range, 2,020 yards. 12 shrapnel. Time, 5 minutes; interval between rounds, 25 seconds:

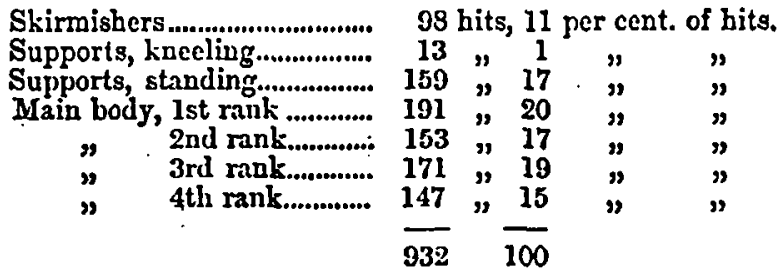

Mean burst of shrapnel; 62 to 68 yards short; 10 to 13 feet abore plane. 39. 6 guns with teams, advaricing in section column with 16 yards interval 
aud distance. Total depth of target, 82 jards. Range, 2,080 jards. 2 shrapnel. Time, 9 minutes ; interval between rounds, 19 seconds.

\begin{tabular}{|c|c|c|c|c|c|}
\hline 1st section & 3381 & hits, & 31 & er ce & t. of hits. \\
\hline 2nd section & 300 & $"$ & 33 & ." & $"$ \\
\hline 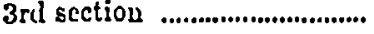 & 303 & $"$ & 33 & $"$ & $"$ \\
\hline & 41 & & 100 & & \\
\hline
\end{tabular}

IIean burst of shrapnel, 68 to 70 yards short; 16 to 18 feet above plane.

40. 'Three ranks of cavalry; each of 10 files, swinging' targets; in echelon, left in front, with 11 yards distance. The battery changes the lirection of fire to the left. Range, 330 yards: 1 shrapnel and 12 case. Time, 2 minutes; interval between rounds, 9 scconds.

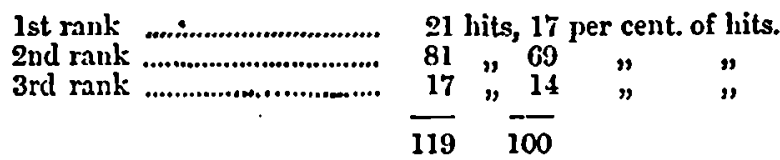

41. Target as in 25 (moving target). Range, 2,190 to 1,640 yards. 12 common and 12 shrapnel. Time, 10 minutes; interval between rounds, 25 seconds.

45 lits.

IIean burst of common, 63 yards short.

Ditto of shrapnel, 50 to 59 yards short; 13 to 10 feet above plane.

Tth Series. 27 th Jifarch. At Thun._- I squadron of cavalry in half coliumn shors itself at the back of the practice ground (42); when these have been driven off, a battalion of infantry in company colunu is seen more to the front; this is compelled to extend ( 13 ). On its left, a battery tries to advance in column of sections (4.1), but is beaten back as it moves. In the mean time more infantry (45) in column of fours comes down the lill. The hostile battery succeeds in tiring a few rounds (46), but is silenced. The infantry has now extended to the right, and is moving against tlie battery; appearing on the plateau from time to time, as it crosses the ravines, first as a. main body (47), then as the front rank of a column of the attack (48), next as skirmishers (49), and, lastly, as rushing in on the battery (50).

42. 5.1 cavalry dumnies in 3 ranks of 18 files, with 20 yards distance, in cchelon, left in front. Range, 2,620 yards. 30 shrapnel. 'lime, 10 minutes ; interval between rounds, 20 seconds.

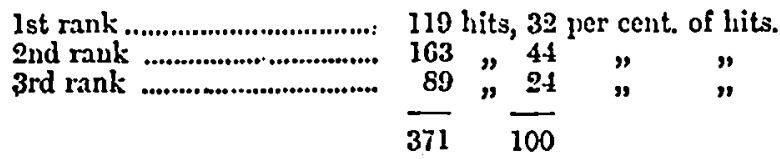

Mean burst of shripnel, 90 yards short; 19.5 feet above plane.

43. 320 standing infantry in four section-columns, each of 4 ranks of 20 men, at 10 paces distance; the two rear columus with an interval of 28 yards ; the two front columns (110 yards further to the front) with 110 yards interval. Range, 2,350 yards. 36 shrapnel. Time, 11 minutes; interval between rounds, 18 seconds.

1 Sec Note, page 140. 


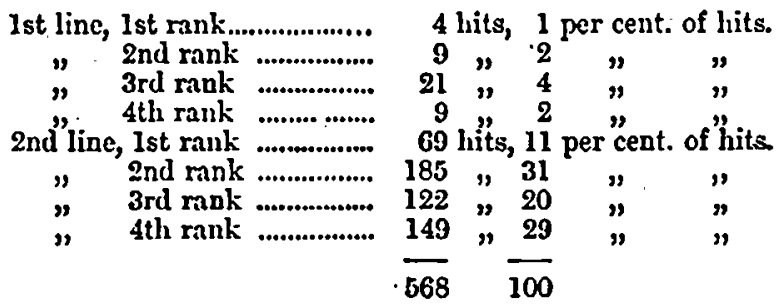

Mean burst of shrapnel, 83 yards short; 15 feet above plane.

44. A battery on the move, in section column; interval, 16 yards; distance between scctions, 2 paces; length of column, 55 yards. Range, 2,210 jards. 30 shrapnel. Time, 9 minutes; interval between rounds, 18 seconds.

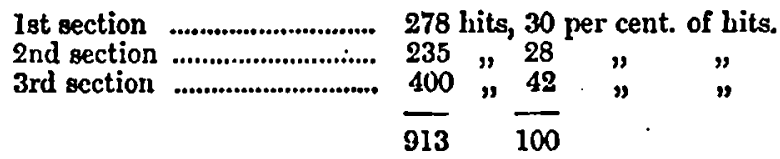

Mean burst of shrapnel, 74 to 77 yards short; 12 feet above plane.

45. Target as in 33. Range, 2,620 yards. 6 common and 18 shrapnet. Time, 7 minutes; interval between rounds, 17 seconds.

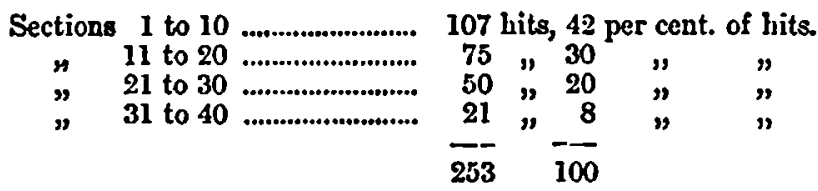

Miean burst of common, 92 yards short.

Ditto of shrapnel, 96 yards short; 27 feet above plane.

46. A battery unlimbered, 6 guns firing. The limbers on the flanks 25 with target 23. Range, 1,750 yards. 18 common and 12 shrapnel. Time, 10 minutes ; interval between rounds, 20 seconds.

Guns

Limbers
137 hits, 19 per cent. of hits.

$\frac{584}{791} " \frac{81}{100} "$ "

Mean burst of common, 48 to 50 yards short.

Ditto shrapnel, 50 to 52 yards short ; 8 to 9 feet abore plane.

47. Infantry, standing, in section columns, 4 rows of 20 dummies with 10 paces distrnce; the fire to be directed on one column only. Range, 1,970 yards. 2 common and 18 shrapnel. Time, 6 minutes; interval between rounds, 12 seconds.

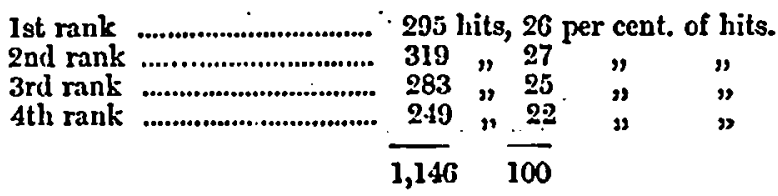


Mean burst of common, 59 yards short.

Ditto of shrapnel, 63 yards short.; 9 feet abore plane.

48. 90 files, each of 5 standing infantry, on 4 disappesring targets. Range, 1,530 yards. 12 common and 12 'shrapnel. 'Time; 8 minutes; interval between rounds, 20 seconds.

$$
\text { 1st rank........................................... } 108 \text { hits. }
$$

Mean burst of common, 41 yards short.

- Ditto of shrapnel, 44 yards short ; 7 feet above plane.

49. 3 groups of knceling infantry, cach of 10 men, on swinging targets. Range. 1,040 Jards. 19 shrapnel. Time, 5 ruinutes; interval between .roundi, 14 seconds.

$$
\text { 1st rank....................................... 124 hits. }
$$

Mean burst of shraphel, 22 to 24 yards short ; 8.5 to 9 feet above plane.

50. 4 groups of kneeling infantry, each of $10 \mathrm{men}$, on swinging targets. Range, 330 yards. 8 shrapnel and 6 case.. Time, 1 minute; interval between rounds, 4 seconds.

$$
\text { 1st rank....................................... } 79 \text { hits. }
$$

8th Series. 28th Narch. At Gürbenihal.-Fire will be opened on a battery (51a) which is adrancing; when this has been made to halt, some wagons which are 330 yards in rear of it in a hollow will be attacked (51b). " In the meantime, infantry (52) come up on the left of the battery; these advance in two cchelons (53) and extend in groups (51). The latter advance, being opposed by our skirmishers (dummies with their backs turned to the guns); the enerny, in a crowded formation, divides into a main'body (55) and an advanced troop (50), and must be engaged over the heads of our own troops. The enemy's attack is stopped, and while drawing off in column of march, he is fired on at long range (57). The whole of the practice (252 rounds) is to be carried on without internission.

5la. 6 guns, supposed to be moving, the detachments dismounted, the limbers horsed. Rangc, 3,300 yards. . 18 common. Time, 10 minutes; interval between rounds, 33 seconds.

$51 b$. 6 horsed wagons, detachments dismounted, teams facing to front 330 yards in rear and 55 yards to the flank of the battery, in a partially covered position, in section column, closed to 4 paces. Range, 3,770 yards. 18 common. Time, 5 minutes; interral betpeen rounds, 16 seconds.

$$
\begin{aligned}
& 3,390 \text { yards, limbers and teams .... } 12 \text { hits, } 46 \text { per cent. of hits. } \\
& \text { Guns and detachments................... } 11,43 \text { " " } \\
& 3,720 \text { yards, lst section wagons.... . . 1 " } 4 \text { " } 4 \text { " " }
\end{aligned}
$$

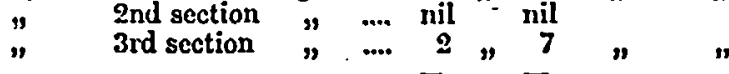

$$
\begin{aligned}
& \frac{2}{26} " \frac{7}{100} "
\end{aligned}
$$

Yean burst of common, 40 to 142 jards; 161 to 163 yards short.

52. 40 standing infantry, 2 ranks of 20 men, at 10 paces distance. Range, 3,600 yards. 24 common. Time, 7 minutes; interval between round; 18 seconds.

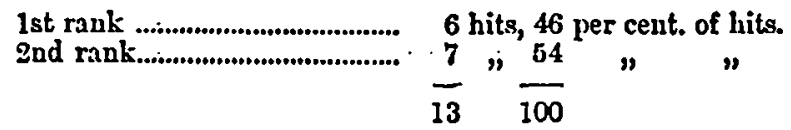


Yean burst of common, 155 yards short.

53. Two lines each of 20 stauding men, distance 135 yards. $\therefore$ Interval, 50 yards. 'Range, 3,390 yards. ' 36 ahrapnel. Time, 14 ninutes ; ' interval between rounds, 23 seconds.

lst line

111 hits; no hits on 2 dine.

Méan burst of shrapnel, 145 to 147 yards short; 32 feet, 20.5 feet, and $12 \cdot 5$ feet above plane.

51. 4 groups of 10 skirmishers kneeling, each group about 16 paces wide, half: covered behind the bank of a road. Range, 3,170 yards. - 36 shrapnel Time, 19 minutes; interval between rounds, 32 soconds.

56 hits.

Mean burst of shrapnel, 127 to 129 yards short; 29 to 35 feet abore plane.

55. 40 infantry, 2 ranks of 20 men, with 10 paces distance; the rear rank standing, the front knceling. Rauge, 3,060 yards '48.8hrapnel. 'Time, $S$ minutes; interval between rounds, 10 seconds.

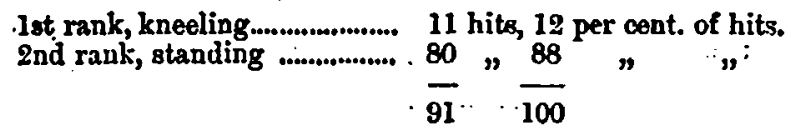

Mean burst of shrapnel, 118 yards short ; 23 feet above plane.

56. 6 groups of 10 . files of kneeling infantry; about 330 yards in front of target No. 55; between 55 and 56, in rear of the 2nd and 5th group, are supports of 20 men each, standing in liue; our own troops are 275 yards nearer to the guns. Range, 2,620 yards. 48 shrapnel. Time, 20 ininutes ; interval between rounds, 25 seconds.

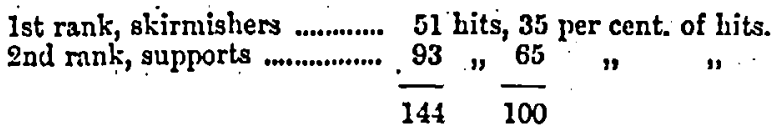

Mean burst of shrapnel, 90 to 99 gards short; 15.5 to 20 feet above plane. 57. Infantry iu column of sections, 80 men in 4 ranks of 20 ; with 10 paces distance. Range, 4,040 yards. 24 common. Time, 10 minutes; interral between rounds, 25 seconds.

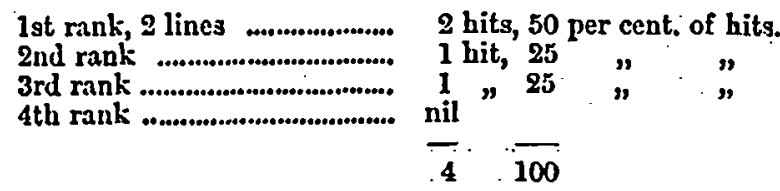

Mean burst of common, 189 to 211 yards short.

Time for the whole 252 rounds, 95 ininutes; arerage interval between rounds, $22 \cdot 6$ șeconds.

9th Series. 28th March. At Gürbenthal.-An enemy's battery opens fire, and is answered (58a); after supposed success the limbers, which are on the flank of the hostile battery, are attacked (58b). Infantry adrance in front of the battery ; they hare extended from company column, and represent the reserve; fire is opened in succession on the reserve (59), the supports $(60)$, and the firing line (61). When this attack has been repulsod, the enemy tries to hold a position farther to the rear (62), but is dislodged. Cavalry 
come up in the background, but are driven back. The whole series fired consecutively.

58a. 6 guns in position with detachnente, marked by puffs. Range, 2,900 yards. 24 common and 24 shrapnel. Time, 27 uninutes; interval between rounds, 34 seconds.

686. The limbers of the battery, about 110 yards to the rear, and 66 yards to a flank, in colunus of sections, close intervals, teams facing the rear. Range, 3,060 yards. 18 shrapuel. Time, 10 minutes; intervals between rounds, 33 geconds.

2,900 yards, guns and detachments.... 70 hits, 40 per cent. of hits,

3,060 " limbers ............................. 120,60 " "

$\overline{190} \cdot \overline{100}$

2,900. Mean burst of common, 122 to 124 jards short.

Ditto of shrapnel, 124 to 156 yards short; 27 feet above plane.

3,060. Mcan burst of shrapnel, 136 short; 12 feet above plane.

59. Two columns of sections, 80 men in 4 ranks of 20 , with 10 paces distance. Range, 2,020 yards. 18 common and 24 shrapnel. 'lime, 8 minutes; interval between rounds, 11 seconds.

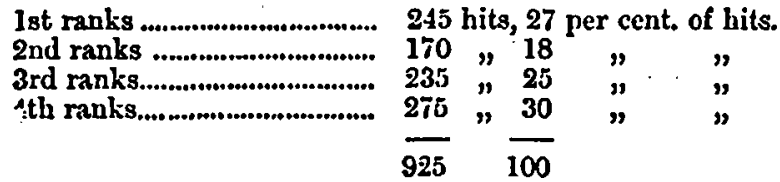

Mean burst of common, 61 to 63 jards short.

Ditto of shrapnel, 66 to 68 yards short; 21 to 28 feet above plane.

60. 2 squads 220 yards further to the front, each of 40 men, in 2 ranks, with 10 paces distance, kneeling, with intervals of 176 jards. Range, 1,800 yards. 24 slirapnel. Time, 6 minutes; interval between rounds, 15 seconds.

lst rank

2rid rank
144 hits, 54 per cent, of hits.

$\frac{124}{268} " \frac{46}{100} "$ "

Mean burst of shrapnel, 55 to 55 yards short; 9 to 15 feet above plane.

61. A thick firing line of 6 groups of 10 men kneeling, with 4 groups of 10 men kneeling covering the outer intervals: Range, 1,640 yards. 24 shrapnel. Time, 5 minutes; interval between rounds, is seconds.

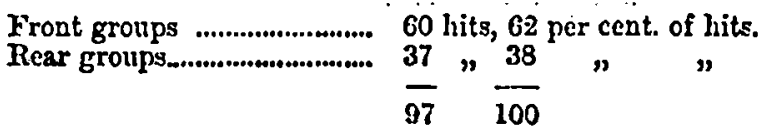

Mean burst of shrapnel, 45 yards short; 13 feet above plane.

62. 6 groups of knceling infantrj, each of 10 men; width of a group about 16 paces, that of the whole line about 110 yards. Front irregular. Range, 2,300 yards. 12 common and 32 shrapnel. Time, 13 minutes; interval between rounds, 17 seconds.

163 lits.

Mean burst of common, 70 to 72 yards short.

Ditto of slurapnel, to to 72 jards short, 21 fect above plane. 
63. 36 cavalry (2 sections) in 2 ranks of 18 men, with 20 yards distance. Range, 4,150 yards. 13 common and 6 shrnpnel. Time, 5 minutes; interval letween rounds, 16 seconds.

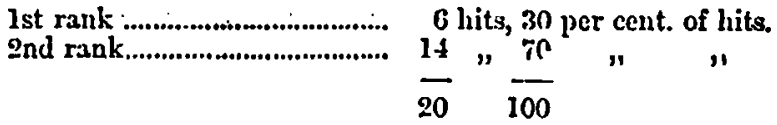

Mean burst of common, 187 yards short.

Ditto of shrapnel, 187 yards short : 40 feet above plane.

Time for the whole series (219 rounds) 80 minutes; aremge interval vetween rounds 22 seconds.

The record of the effect on the various targets gives the above results, in which the effects of shrapnel and of ring-shell are taken together; for the further deductions which it is proposed to draw, the effect which was the cousequence of the united action of shells and shrapnel will be merely taken as caused by so many rounds. Materials are available which would render it possible to distinguish the separate effect of each projectile, but to do so would entail endless labour, without making any important alteration in the amount or value of the information to be obtained.

\section{Comparisons and Conclusions.}

Even a cursory glance at the results of this practice gives the impression that the effect of the wide-bursting projectiles of artillery increases with the depth of the target, and only partially with the width; it is worth while to go a little more into this question.

The foregoing results are certainly the first which we have obtainied, while a satisfactory conclusion can be derived only from a series of trials with similar factors; it is, therefore, not merely a matter of interest, but one of duty; to repeat and complete such practice; but to do this would need a great expenditure of ammunition, and this nust be spread over several years and courses. An immediate and approximate judgunent is, however, lesirable, and it is possible to make a comparison of the results if we use a process which is perliaps rather arbitrary.

In order to compare the question of formations, similar bodies of troops must be taken together, and in combination with the three factors: number of rounds, range, and size of the target or of the number of targets.

The first factor may be arrived at with sufficient accuracy, if the six first rounds be deducted from each series, and if the number of hits be divided by the remaining number of rounds, which will give the number of hits for each effective round; this proportional number should then, for each series or formation, be multiplied by some common number of rounds, say 72 .

This corrected number of hits must then be fairly adjusted as regards the range; a correct computation must have for its basis the-length of the dangerous zone which corresponds with the particular size and range of the target. Since, however, an approximate comparison only is possible, it will be sufficient to take account of the most important factor-the angle of descent-and to multiply the corrected number of hits by the tangent of this angle. A comparison of the actual number of hits with the same when corrected by the angle of descent will enable us to judge whether this mode of proceeding may lead us to expect to thus make an approximate estimate of value. 1

1 It may pcrhaps be well to explain the system pursued in the following tables a little mort fully.

rOL: IXIY. 
We must, finally, cndearour to assimilate the targets by means of a factor; which shall in a simple mancer correct their several ratios ; thus a fire which is directed on 4 guns can be compared with one carried out on 6 by multiplying the number of hits by $1 \cdot 5$.

With respect to infantry, the following points may be deduced :--

1. The best formation for a battalion.

2. The best formation for a compans.

3. The thichness of men in the firing line.

4. A comparison between standing and kneeling targets.

Owing to the insufficiency of the amount of practice, we lave not sufficient data for the caralry ; at the most we can only compare the column of sections and the half column.

With regard to the artillery, we may learn-

1. The proper position for the ragons.

2. That for the limbers.

3. The effect of column formations.

4. What is the risk of movement within range of the enemy.

It is not the object of this paper to bring to notice every point which might be of value, since for this we must frat obtain further information; it is merely as it were a provisional sign-post, pointing out in which direction we should seek for furtlicr experience, and make a further comparison : the present work is only the first effort and the first contribution towards the solution of this important question.

If we compare the results given above, we shall arrive at the following data :- -

2. Againet Infantry Targots,-1. The formations of the battalion (320 dummies) are as follows:-

30. A battalion in double column.

32. A battalion in liut four deep.

34. A battalion in line of columns.

43. A battalion in company columns.

55. and 66. A battalion in the act of extending.

59 to 61 . A battalion extended.

The firot column given the number of the practice which is to be considered,

The second column girce the number of rounds sctually fired in that practice.

The third number shows this number minus six rounds deducted as ranging rounds.

The fourth column gires the total number of hits obtained in the practicc.

The fifth column showe the quotient of the fourth column dirided by the third, giving arerage of hits for cech round.

The wixth column is the fifth column multiplied by 72 , showing the hits which would hspe been made had 72 rounds been fired st each target.

The seventh column gires the rango in yards for each practice, and the eighth the tangent of the consequent angle of descent multiplied by 1,000 .

The ninth column shows the product of the sixth multiplied by the eighth.

It is considered that the rarying conditions of the sereral practioes are thus reduced to a common standend for the purpose of comparison. $-\mathrm{N}$. L. W. 
UF THE SKTS, FUEXV

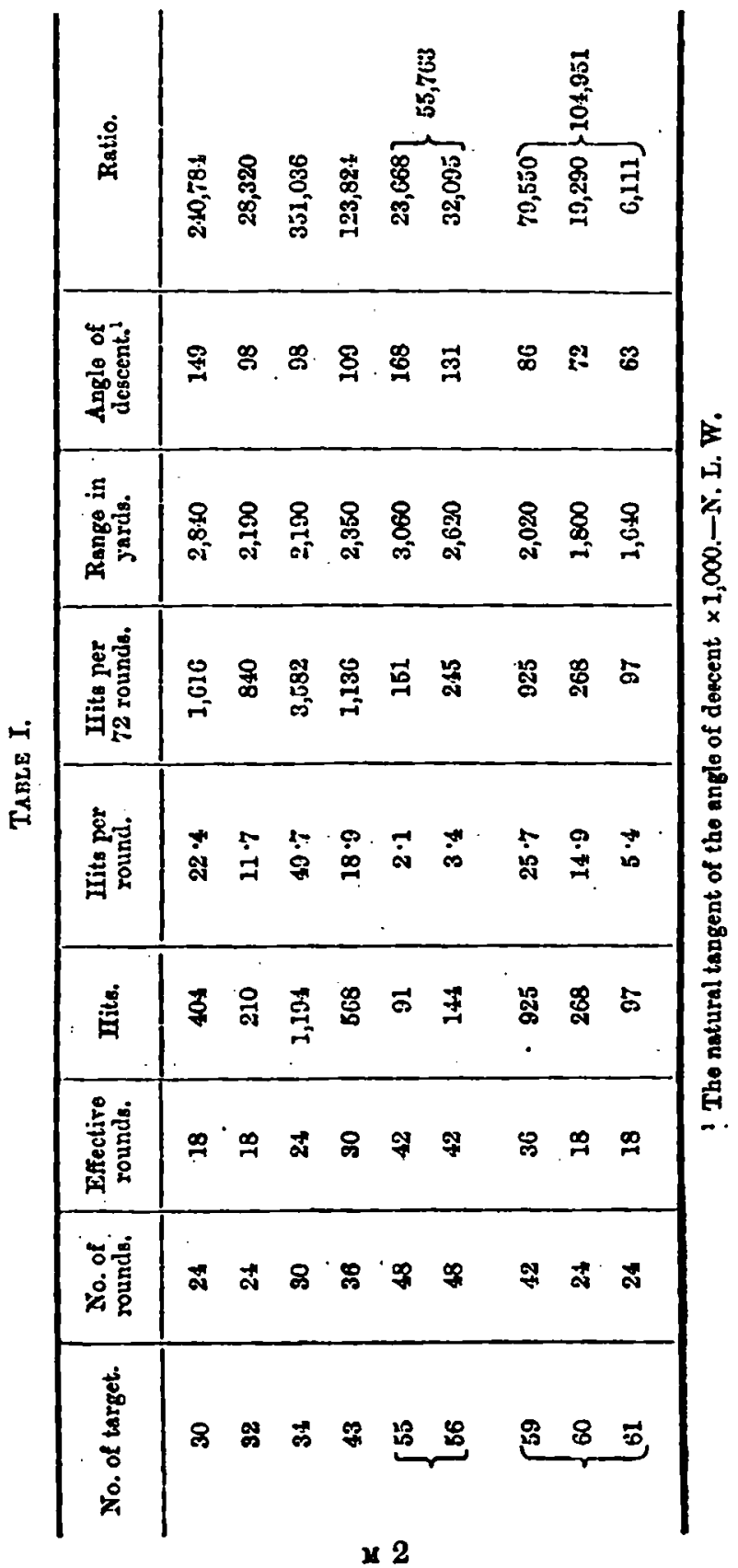


Thus the effect stanels in the following order :--

1. 34. Battalion in line of columns.

2. 30. Battalion in donble colunn.

3. 43. Battalion in compauy column.

4. 59 to 61 . Battalion extended.

5. 32. Battalion in line four deep.

6. 55 and 56. Battalion in act of extending.

If the rauge be taken as the factor in place of the angle of descent, the table of effect will stand exactly in the sane order.

The above tahle show's at once that the most crowded targets are the most dangerous. The fact that the line of columns receives more hits than the donble column can be explained by the circumstance that with the former the fronts of all four colimns are at the same distance, and that it is thus easy to carry out the distribution of fire, while the target is deep enough to catch all shell that are too high to hit the front rank, which is the true target.

$A$ double columu is twice as wide as a scction column, and it is very improbalule that many shell will fall to the right or left of it; if it shows fewer hits than a line of columns at half deploying interval, this is due to the fact that the guns are laid on the front rank, and that normal rounds produce an effect only as far as the third or fourth rank; only a few shell, which fly too high, will strike the rearmost rauks.

It would seetn as if greater effect shonld be obtained on the double column; but to do this would entail a cliange in clevation. Such a proceeding, however, can be used for fixed targets only; and we are thus brought to the conclusion that a battalion which, when within sight of the eneny", advances in line of columns runs nore risk than if it were formed in double columu. 'Target No. 43 shows what a difference it makes if all parts of the target are at the same distance from the guns. For it is rirely possible to decide from the battery as to which are the leading companies, unless all four companies can be observed directly from the front, and it can thus be determined that the flank companies are the foremost; as a rule, those which stand highest are taken to be the foremost, and vice versh. This circumstrnce makes the distribution of fire exceedingly diffieult, especially when all four companies are also in morement. It thus seems that an advance in company columns is advantageous, when the enemy's artillery does not occupy a higher level than our infantry ; but we further learn, from turget No. 32, that another formation, the line four deep, is yet more advantageous.

The fict that the effect on the line four deep stands in the table between the results obtained on the extended formations of the battalion is not solely to be ascribed to the particulir practice (though the burst of the shell wis too short, 176 to 187 jards short), since the target stood exposed on good even ground, on which the breadth of the burst must have been alvantageons, and on which even ricochet hits might be expected. It arises rather from the small depth of the target; this is clearly shown in Targets 59 to 61 , where the percentage of hits increases not witls the number, but with the closeness of the targets, that is to say, with the depth of target. If we renember that a line of two or four ranks will not suffer at all from such shell as pass over it, while, on the other hand, troops when extended according to regulation, will find that such .shell as are too high to hit the foremost rank will strike the supports or the reserve, it becomes a very serious question whether infantry, who are within reach of hostile artillery fire, inay not be best formed for the advance, either with the battalion in four closed ranks, or as a line of companies two deep. It is also a matter for consideration whether the advautage of easily 
finding cover is of such great importance, that with this object the desirability of the mutual support and the close conuection of the lines can be disregarded. With extended and, as is the case in practice, close and strong lines of skirmishers, experience teaches us that the use of small cover afforded by the ground is often neglected; deep well-marked cover is always taken advantage of ; the lines are sure to get crowded there, and often to such an crtent that we find them in four or more ranks, but in no sort of order. If we take account of the effect of infantry fire on such formatione, we may theorize on the advisability of the adoption of a formation compounded of that of Frederick the Great with that of Napoleon, including the occupation of the front with thin lines of skirmishers, the advance of the reserves under artillery fire in two or four closed ranks, an extengion into two ranks when within the zone of infantry fire, the skirmishers being absorbed (on the flanks, as is now the case), and, finally, the assanlt on a serried line.

In comparison with the effect against a whole battalion, let us take those against a single company.

2. The formations of a company are as follows :-

22. Column of sections.

24. Column of sections, broken up.

33. Column of files.

45. Do. do.

47. Column of sections.

55 and 56 . Company extended.

57. Column of sections (at a long range).

60. Two subdivisious in column of sections.

61. Company in groups. 


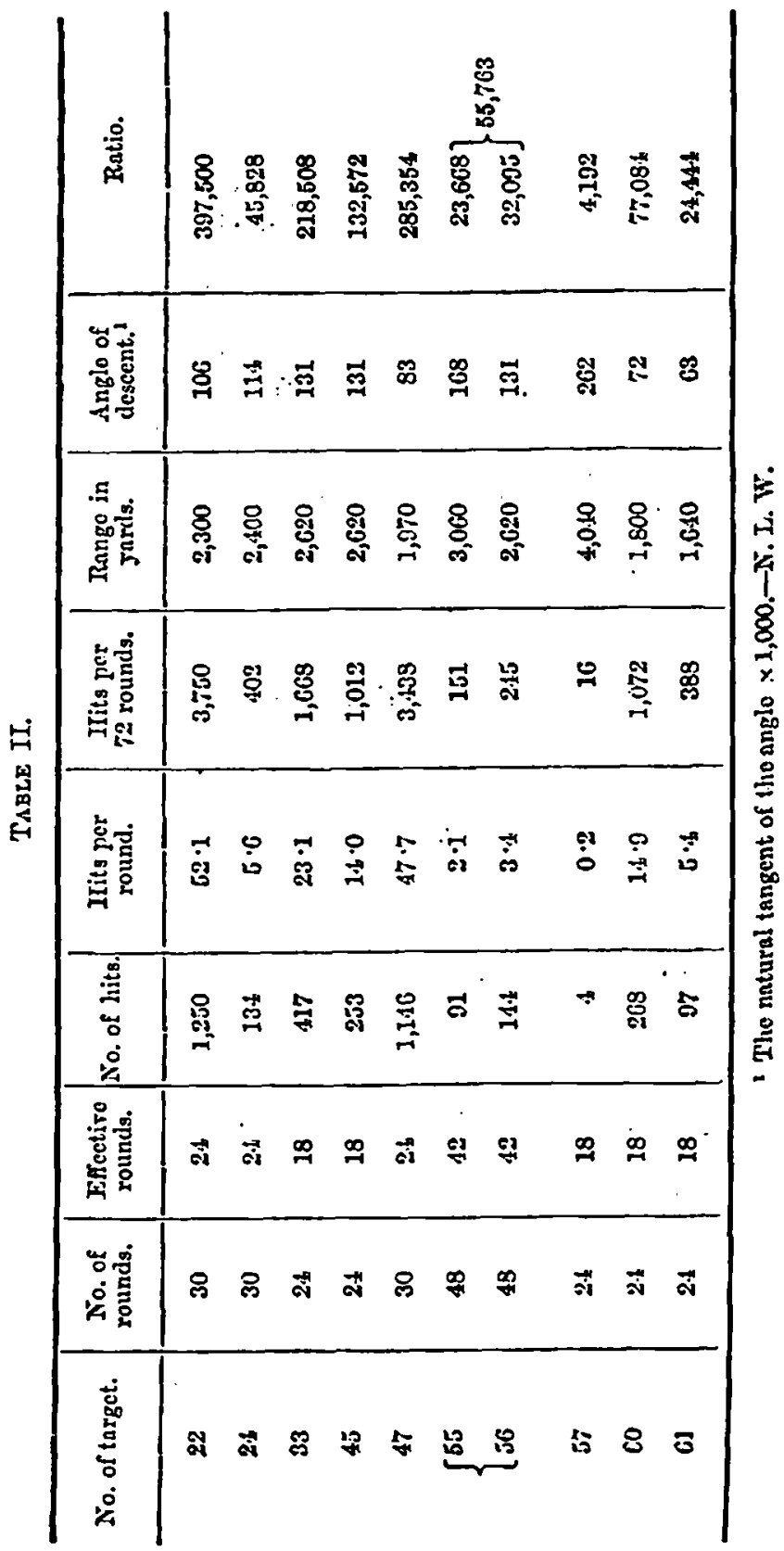


Thus the effect stands in the following order:-

1. 22. Column of sections.

2. 47. Do. do.

3. 33. Column of fours.

4. 45. Do. do.

5. 60. Tro subdirisions in colunn of sections.

6. 55 and 56. Company extended.

7. 24. Column of sections, broken up.

8. 61. Company in groups.

9. 57. Coluinn of sections (at a long range).

Target No. 57 may be struck out of the foregoing table, on account of the long range and the fact that common shell only were used, since these projectiles struck the soft ground at a high angle and buried themselves.

After the comparison which has already been nade, it is not surprising to fiud that the column of sections of the entire company is the most unfavourable for safety ; following the theory of the effect of the depth of a column, the column of fours holds with a company almost the same position as does the double column in the case of a battalion ; it is indeed closer, but on the other liand it is smaller. It must also be observed that in the instances quoted the columns of fours did not move directly against the battery which was firing on them, while they were, moreover, at a varying distance from it. Many shell must also have fallen to one side of them, many must have been short, while there were, so to spcak, no ricochet hits; both results warn us again against a deep formation.

The results a aainst the four other company targets, viz., that in subdivisions (each being in colunn of sections) and those when fully extended, give very nearly the same effect. Even when the difference of range of one half of the company is so insignificant, as was the case with Target No. 24, it is obvious how difficult it is to distribute the fire; the fact that No. 24 target showed less effect than the widely divided Target No. 60 is accounted for by the more easy obserration of fre which was possible with the latter, owing to the higher station of the battery when firing at it: under similar circunstances Target No. 24 must have received more hits than Tasget No. 60.

If then targets divided into tro parts, with small intervals and distances between those parts (each of these consisting of two ranks at ten paces distance), are not nore unfaroumble to safety than a complete extension, nothing prevents our arriving at the conclusion that the advance of a company under artillery fire in two subdivisions in column of sections (which are less than a musket-shot apart), while it has great advantages as regards the conduct of masses of troops, is not more dangerous with respect to the effect of fire than would be the case with the normal extension into groups and supports, or into groups and reserve. There is no doubt that even this effect can be still more diminished if the rear sections open out while adrancing, or if the two sections, each four deep, place themselves side by side, while this latter formation gives an even smaller depth.

The difference between the results on Targets Nos. 60 and 61 , which were fired at under very similar conditions, compels us to make some reference to the effect of the close nature of the target; in doing this we must take into account the number of men in the skirnishing line.

3. Closeness of kneeling skirmisher lines.

35. 6 groups, 60 kneeling men, factor 1.66

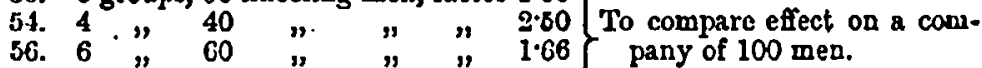

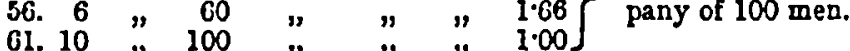

61. 10 " 100 " $1 \cdot 00$ 
164 : TACTICAL DEDUCTIONS FROM THE PRACTICE

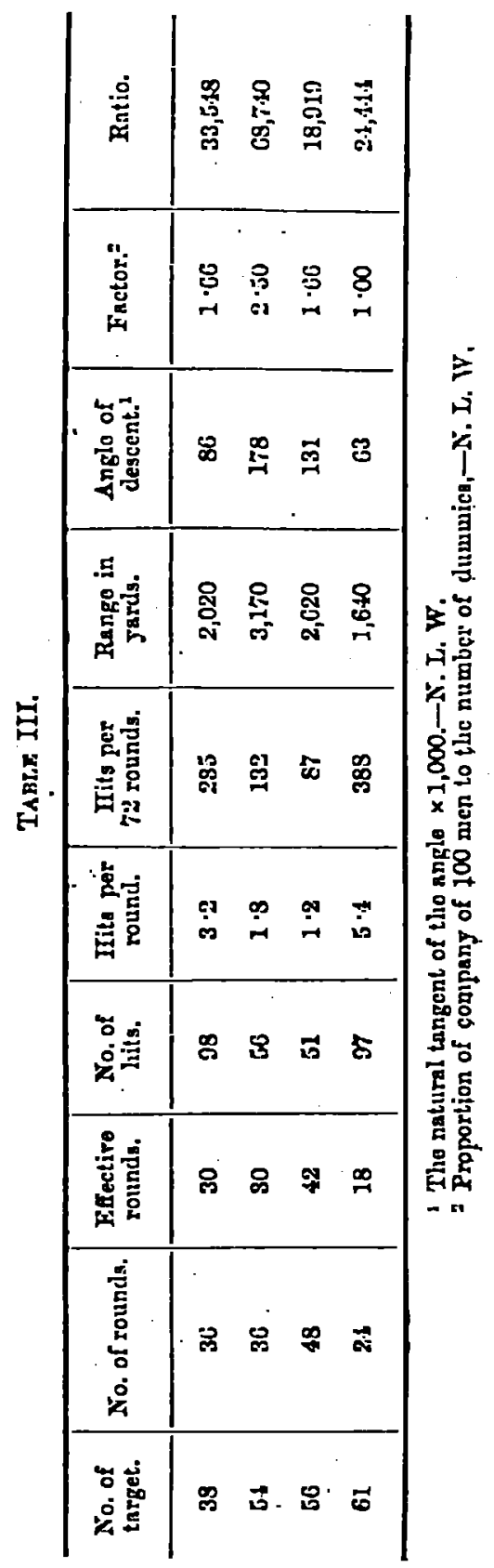


Thus the effect stands in the following order:-

I. 54. 4 groups kneeling.

2. 38. $6 "$

3. $61.10 "$

4. 56. 6 "

13

$1)$

One would have thought that the number of hits would have been con. siderably increased, when a larger number of men stood on the same space; and in a certain sense this must be true. But against this supposition is the fact that it is easier to distribute the fire over a broken line of groups than when the whole of the visible target shows as a complete line.

The above unexpected results show that a thickening of the lines of skirmishers on a given front, or a closer concentration of them towards one spot, docs not expose them to any greatly increased danger from artillery fire; in any case that danger is not, under any circumstances, subject to such an increase as would be given by a deep formation. This statement assumes, however, that the height of the target is not such as to give the effect of depth. The following tigures show what a difference the height of the target will make :-Targets Nos. 32 and 55 have each a front rank kneeling and a rear rank standing; the percentage of hits on the kneeling are 45 and 12 , while those on the standing are 55 and 88 . Taking the mean, we find that under an equal fire the kneeling line will receive three-tenths of the hits, and the standing Beven-tenths; in other words, the effect on the standing is more than double that on the kneeling line. This comparison further informs us that the effect of bursting shell is but little increased by the breadth or the closeness of the target, but that the height or the corresponding deptb are the real factors which increase effect, and which must be considered when selecting tactical formations to be used under artillery fire.

b. Against Cavalry Targets.-The limited practice against cavalry gives the following results :-

4. The formations of cavalry were as follows:-

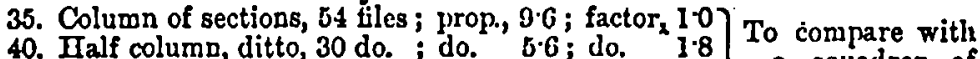

40. IIIf column, ditto, 30 do. ; do. 5.6 ; do.

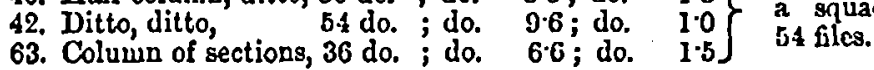




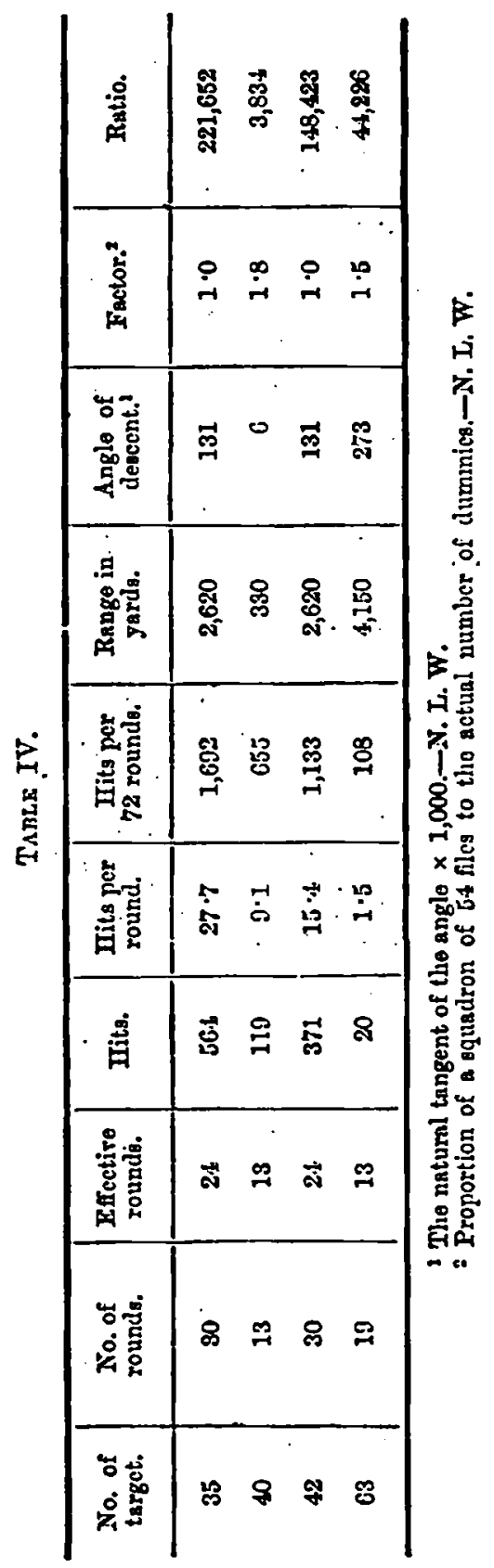


Thus the effect stands in the following order :-

1. 35. Column of sections.

פ. 42. ITalf-column.

3. 63. Column of sections.

4. 40. Half-column (at 320 sards with case).

Of these only 35 and 42 are of use to enable us to form an opinion; the depth of both targets is the same, but the half-column of target 42 becomes less close as the width increases; thus the results imust be nearly the same. This would not be the case with a squadron in line, if such a comparison could be made ; from what we hare already learnt, we niay conclude that in this latter formation the risk of loss under artillery fire, especially on the move, would be very sinall, probably cven less than would be the case if the sume front were covered by an attack in swarms, since this would imply a grenter number of targets in depth.

This opinion is atrengthened by the effect on Target 40, where the second (that is to say, the centrc) rank shows the greatest unmber of hits by case. This description of projectile, when used against broad fronts and at a short rnnge, gives the best distributed, and, therefore, the greatest, effect; the difficulty is for the artillers to gire proper attention to the distribution of fire at moments of intense excitement; if this could be done, it might be possible to use also shrapnel with the tine fuze carefully set; with regard to the last period of the charge, the effect will depend mainly upon one thing, viz., whether the line of charging cavalry is in open or close order; but even in this case the depth of the formation will act prejulicinlly.

c. Agrinst Artillery Targets.-The third group of records concerng fire ngainst artillery targets, composed of either the whole battery or of the guns and linbers only. In order to compare 4 -gun batteries with 6 -gun, the hits on the former must be multiplied by 1:5.

i. 'Ihe formations of artillery are as follows :-

'The whole battery.

27. With wagons at 80 yards distance.

31. With wergons at 330 yards distance, on either flank.

30 and 37 . With wagons under cover ( 4 guns and 4 wagons).

$51 a$ and $51 b .6$ guns unlimbered, 6 wagons in colımn of sections, 360 yards to the left rear of the guns. 


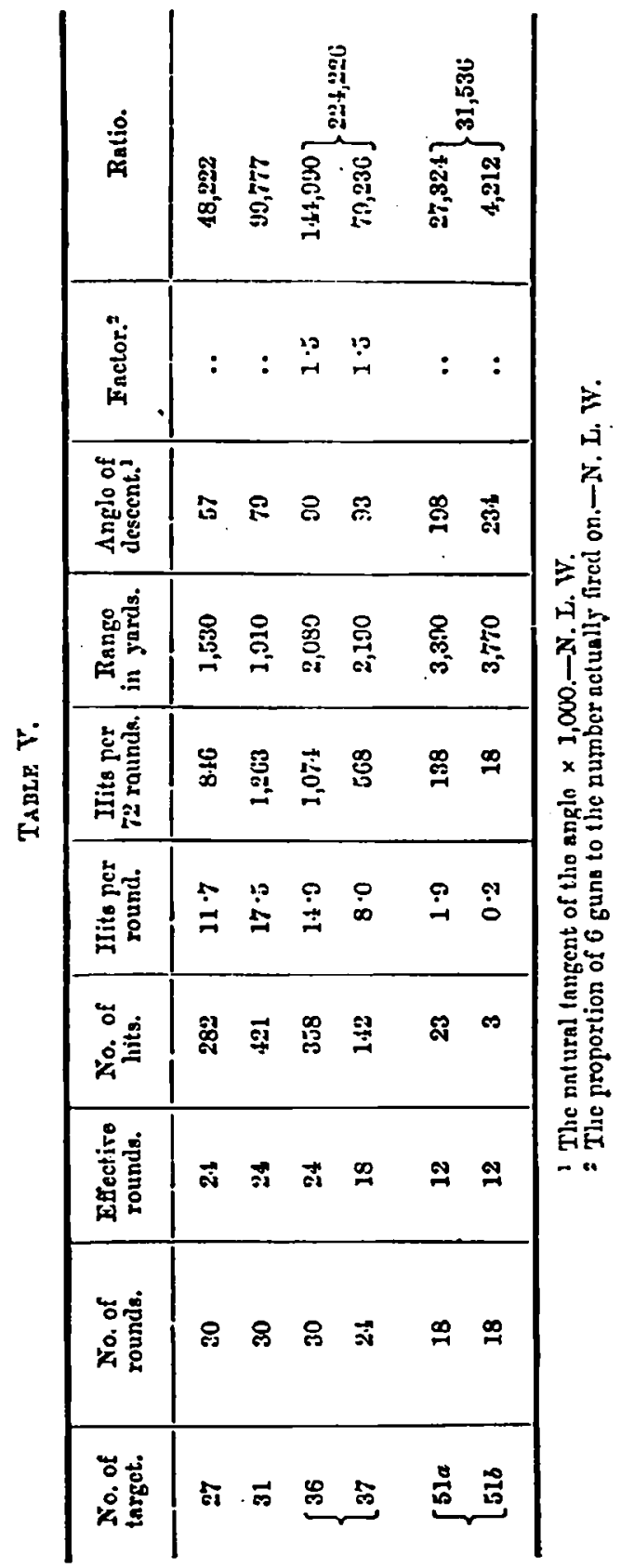


Thus the effect stands in the following order :-

1. 36 and 37. Wagons under cover.

2. 31. Wagons at 330 yards distance, on either flank.

3. 27. Wagons at 80 yards distance.

4. 51a and 516 . Guns in action, wagons in column of sections 360 yards to the left rear.

The above can be compared with the following percentages of effect on the whole battery :-

\begin{tabular}{c|c|c|c}
\hline $\begin{array}{c}\text { No. of } \\
\text { target. }\end{array}$ & $\begin{array}{c}\text { Guns and } \\
\text { detachments. }\end{array}$ & $\begin{array}{c}\text { Limbers and } \\
\text { teams. }\end{array}$ & $\begin{array}{c}\text { Wagons and } \\
\text { teams. }\end{array}$ \\
\hline 27 & 42 & 21 & 37 \\
31 & 26 & 63 & 6 \\
36 and 37 & 29 & 43 & 23 \\
519 and 516 & 46 & 43 & 11 \\
\hline
\end{tabular}

Thus Target No. 31 suffered the least, having its wagons on the flanks 330 yards in rear of the limbers, though 6 rounds out of 30 were specially directed on the former. But the distance of burst was about 220 yards in front of the wagons, which brings us to the statement which has already been made, that shrapnel shell has no effect beyond a fixed depth; in this case the rear dummies were about 269 yirds from the point of burst, which was only about 19 feet above plane. The greatest proportional effect was on Target No. 27, when no special fire was delicered on the wagons, and when the burst of the shell was 220 yards in front of the guns, and thus nearly 300 yards from the rearmost dummies. The strikingly contradictory results given by these two examples can only be explained by the fact that with 'Iarget No. 27 the bullets could ricochet as far az the wagons, which with Target No. 31 was not the case; thus with Target No. 27 the number of hits wins greater, and the effect of ench bullet less, while with Target No. 31 only direct hits were counted.

In the first table the Target Nos. 36 and 37 is at the head of the list; the reason for this is, that the wingons received 23 per cent. of the hits, although they stood behind a covering inass and a screen, though certainly close up to the latter and very near together. The lesson to be learnt from this is again not new, viz., that cover does not shelter deep targets which are on the same level, and that screens are only of value when the object to be hidden stands far in rear of them. The above experience shows us that the distance between them should be at least 320 yards.

When the wagons were placed in line 80 yards in renr of the front of the guns, they received too nany accidental hits; even 320 yards distance did not prevent this ; a separate position, as in Target No. 516, is evidently equally dangerous as one in rear of the battery, if it inplies a considerable depth. The best formation is to piace the wagons parallel to the line of the battery, and in column of route, taking care that they are as far as possible concealed from vien; unquestionnbly the most dangerous screens are such as can be clearly seen, and these again become norse as they are nearer to the battery.

If both the above tables be taken into consideration, the order of the targets, as regards danger, is as follows :-

Nos. 37, 27, 31, 516 .

6. Battery without wagons. 
The following formations were tested :-

21. 6 guns and limbers, teams facing the rear.

23. Ditto, limbers on the flanks.

27. Ditto, limber teams unbooked (wingons not counted).

31. Ditto, normal formation.

36. 4 guns, ditto, ditto.

39. 6 guns, in column of sections at full interval.

44. Ditto, column of sections at half interval.

46. Ditto, with 3 limbers on each flank.

5la. Limbers in front of guns, teans booked in.

$58 a$ and 586. 6 guns, limbers in column of sections, in flank and rear of the gruns. 


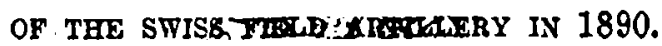

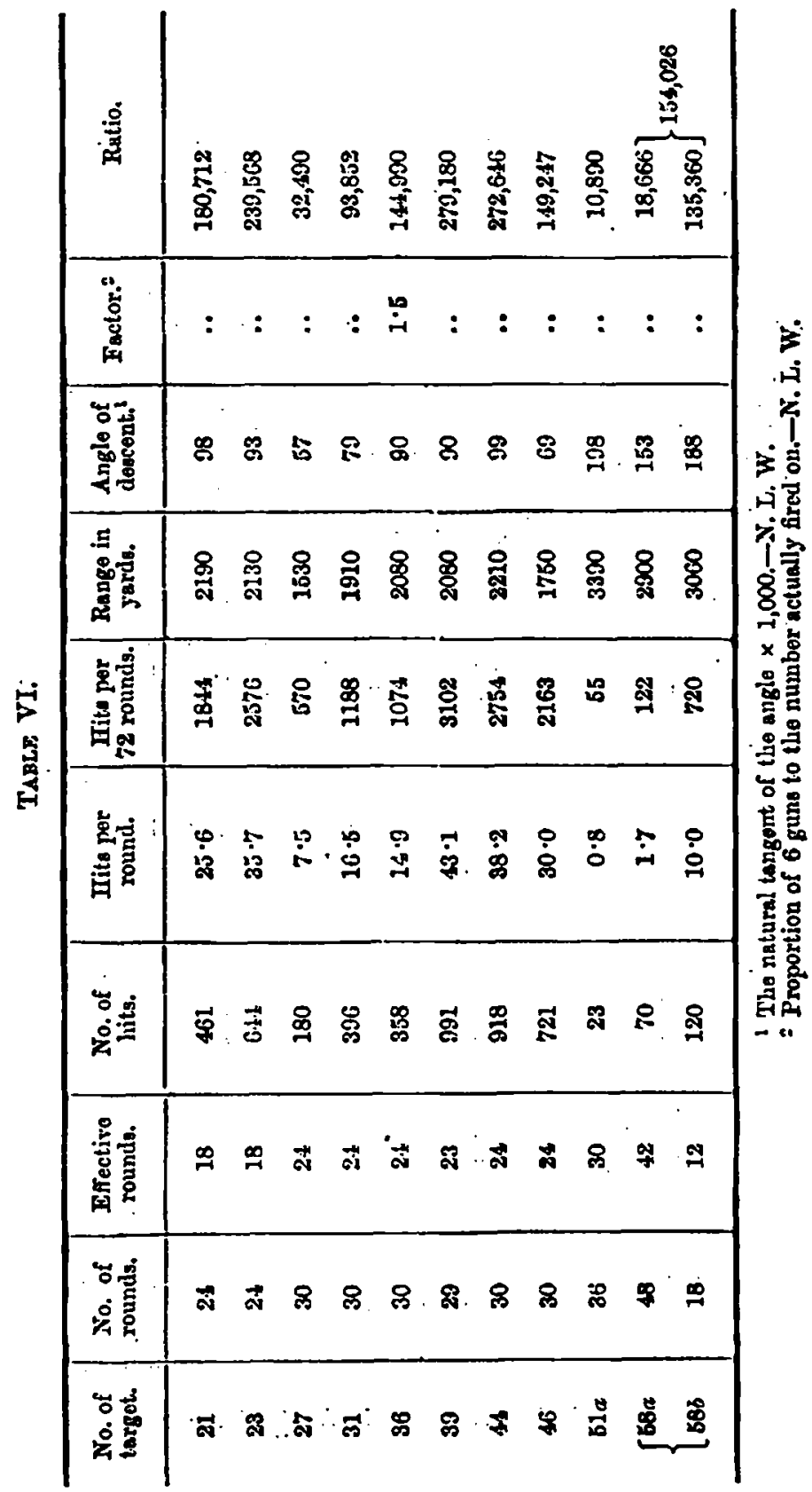


Thus the effect stands in the following order :-

1. 39. Column of sections, full interval.

2. 44. Column of sections, half interval.

3. 23. Battery with limbers on the flanks.

4. 21. Hattery with linbers and teams, normal.

5. 58a and 586. Linibers in column of sectious, in flank and rear of the thins.

6. 46. As with Target No. 23.

7. 36. Normal formation.

8. 31. Normal formation.

9. 27. Normal fornation.

I1). 5la. With horsed guns.

'This comparison gives more certain results than that with the wagons. If we compare the three formations fired at, we find, as we did before, that the line at full interval is the safest and the best formation for movernent. The two columns of sections 'prove themselves to be very dangerous formations, and, since both were fired on under the same conditions, that at full interval was more dangerous than that at half-interral. The apparent contradiction which may be observed, is explained, if we remenber the double column of infantry as compared with the line of columne, while not forgetting that the columns of sections of artillery are half as high again as those of the infantry (9 fect to 6 feet), and if we recollect what a great difference the height of the target made in the comparison between the effect on kneeling and standing lines. In the case of the column of sections at full interval even the very highest bullets of the cone of burst are not lost, as they may well be in the .case of a close column. The columns of sections are really bullet-traps.

Wit.'. regard to the position for the limbers, we have here more informa. tion, for, with the exception of series No. $58 b$, the limbers were not specially fired at; since Target No. 21 comes between Targets Nos. 23 and 46 (where the limbers were on the flanks), we may see that the normal position, 11 yards in rear of each gun, is not so dangerous as an uncovered position showing deptl. If we take the percentage for cach practice, we find:-

\begin{tabular}{|c|c|c|c|}
\hline $\begin{array}{l}\text { No. of } \\
\text { target. }\end{array}$ & Limbers. & Guns. & Limbers. \\
\hline $\begin{array}{c}21 \\
27 \\
31 \\
36 \\
23 \\
46 \\
53 \\
\text { Mrean of the } \\
\text { Mean of } 3 \text { la }\end{array}$ & 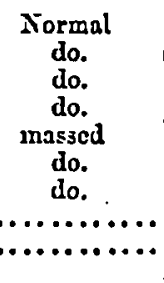 & $\begin{array}{l}41 \\
65 \\
30 \\
33 \\
40 \\
19 \\
40 \\
42 \\
33\end{array}$ & $\begin{array}{l}59 \\
35 \\
70 \\
67 \\
60 \\
81 \\
60 \\
53 \\
67\end{array}$ \\
\hline
\end{tabular}

Thus the limbers will be better posted in rear of the guns, giving a small depth, than in long columans on the flanks.

It is worthy of notice that the limbers receive from three-fifths to trothirds of the hits, a circumstance which can only be ascribed to the large target offered by the teams; this may be observed also with Target No. 5l $\alpha$, where the limbers, which were then in front of the guns, received 52 and the guns only 48 per cent. of the hits; it is therefore certain that, given the present shell and the present formations, the horses will be killel 
before the gumners, and that after the first few rounds the mobility of the battery will be at an end, unless it be accepted as a principle to govern all tactical formations, that the limber:s shall be separated altogether from the guns, or at least that the teams shall be unliooked. Target No. 58b shows that they are by no means safer when they are massed ontsille of tho battery, and still remain visible; even in this case the wiscst thing to do rould be to place the limbers or their tearns under cover, or at some distance in rear of screeins; they must not, however, when in rens of cover, be posted on as to offer a deep tar'get, but snust be on a broad front, either in line with larece intervals (11 yards), or in column of route aloug the line of cover; when behind mere scrcens they nust be at least 320 yards from them, if it be in any way possible to obtain so much distance.

If we endeavour to express the results obtained on the moving targets in terms of those obtained on standing targets, we may assume that the effective fronts of the latter are, taking the moving target as unity, as follows :-

The front of a section of infantry-2.

The front of a section of cavalry-4 or at least 3.5 .

It must be further remembered that the noving tirget represents ouly the front rank. If we take the stationary Target No. Go for comparison, we find that the front rank received 1.44 hits, while the same front with Targets Nos. 25 and 41 (moving targets) received 142 hits, and thus very nearly the same number; there would he the same proportion of hits on the second rank ; if Te increase the pace a little and allow the infantry to pass over the same space in four-fifths of the time, the number of hits will be diminished by one-fifth only.

Passing on to the caralry we may take fire on a column of sections in morement to be represented by Target No. 35.

\begin{tabular}{|c|c|c|c|c|}
\hline & 1st rank. & 2nd rank. & 3rd rank. & Total. \\
\hline 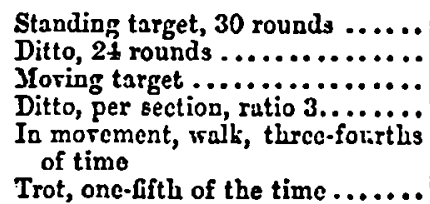 & $\begin{array}{r}15.1 \\
133 \\
71 \\
213 \\
160 \\
43\end{array}$ & $\begin{array}{r}179 \\
135 \\
(f 9 \\
207 \\
155 \\
41\end{array}$ & $\begin{array}{r}201 \\
150 \\
77 \\
231 \\
101 \\
46\end{array}$ & $\begin{array}{l}561 \\
428 \\
217)^{1} \\
651 \\
459 \\
130\end{array}$ \\
\hline
\end{tabular}

Target No. 29 is of great interest ; the moving carringes could be fred on for a space of 185 yards; the battery was ranged on the centre of this space; the time required for a column of 6 carriages to pass it was :-

$$
\begin{aligned}
& \text { The centre space at a walk }
\end{aligned}
$$

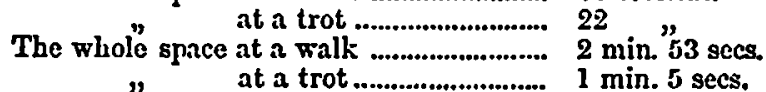

$$
\begin{aligned}
& 60 \text { seconds. } \\
& 1 \text { min. } 5 \text { secs. }
\end{aligned}
$$

The length of column was tro-fifths of a column of 6 guns.

\footnotetext{
The numbers within brackets are cstimated on the ratio of the lst column, riz. : 71 to $138 .-N$. I. W.

TOL. $\triangle \times \times \mathrm{V}$. 
The hits received in 30 seconds were 14 ; this gives for 6 guns at a walk 35 hits, at a trot 13 hits.

It follows that a space of about 220 yards can be passed by the flank match of a battery at a walk withont any considerable risk, even when the enemy's battery is ranged ; but it must be possible for the rear corriages to be able to pass any carriage which miay break down; at a trot there is very little risk. If the space where the column is visible to the enemy is very short, the danger is still more reduced; for example, if it be only 18 yards, there will be but 3:5 hits at a walk and $1: 3$ at a trot. The lesson taught by the othertargets was also true of this, viz., that not the length, but the depth in the direction of the line of fire, of any formation is a measure of its risky character.

It remains to make a few observations which may be of value with regarl to the concluct of fire.

The "rate of fire" is always slower against artillery targets, since the laying must be more exact; the greatest rapidity was 16 seconds betwcen rounds, the least, owing to haid light and long range, 31 seconds; menu, 23 seconds. Cavalry is ensier to see even at long ranges; the rate of tire was fron 16 to 20 ; mean, 19 scconds betreen roumds. Infantry, when nenr, is easier to lay on than cavalry, but at a distance somewhat more difficult on account of its smaller height; rate from 11 to 32 , mean 20 seconds.

At long-continued practice it is found that as a mean, even when the brakes were used, the average pace did not exceed $22: 3$ seconds between rounds; the limits were from 11 to 31 seconds between rounds. After 30 successive rounds from each gon the detachment begin to tire; after 40 rounds there must be a pause; fire should not be kept up for more than 00 ninutes at this rate since the consequent fatigue very mucl diminishes the trustworthincss of the detachment. When the guns linve no brakes two hours must be allowed for 40 rounds, or eren sometimes for 30 ; otherwise the detachment will tire very soon and the service of the gun will de: teriorate.

The greatest pace for rapid fire, if the guns are to be fired more than once, is 4 seconds between rounds; as a rule, the last round will have an interval of 2 seconds; $a$ whole series of 24 to 30 rounds will have $a$ mean of fron 10 to 15 seconds iustead of from 18 to 25 seconds between rounds. Setting the fuzes of shrapnel beforehand accelerates only the first round, and thin very little, since of all the processes included in loading the setting of the fuze is that which takes up the least time.

With regard to the behaviour of the guns, only tro disadrantages show themselves after continued firing. One is, that by opening and closing the breech-rredge a certain amount of powder residue is always collected, which lies at one point of the lands (about 25 degrees right of under); this point must therefore be always looked after, though this can be done only when cne screw is loosened and the breech-block withdramn. On this account, and in order not to injure the gun, not more than 20 consecutive rounds ought to be fired without cleaning the gun; any convenient moment nay bo utilized for this purpose.

If this be neglected the gun does not indeed becone unservicenble, for it can fire 80 rounds or, if necessary, even more; the only consequence will be that the ring and the surface of the bore will be so scored that they will have to be faced. . With smokeless powder there is no such defect.

The otlier disadvantage concerns the lever of the elcvating gear, which is crushed by the recoil at the spot where the onter ring grasps it, with the result that a regular ring of disintegrated wool about 1 centimetre thick in formed on it; tinally the sound part of the lever becomes too weak and breaks at this particular place. Fractures at other points are rare, and aro to be attributed to bad workmanship when making the lever. 
When the brakes are used the point of the trail buries itself less in wet ground than is the case when there are no brakes; the carriage is not injured, if the brakes do not act by jerks. On the other haud, some attention must be paid to the wheels; it is not certain, but it is probable, that the plate of a metal nave gets a set when the brakes are put on hard; after long continued shooting, therefore, the metal naves must be looked to, although eren if the plate be bent the wheel is still serviceable.

Another fact to which attention should be drawn is, that with the present aumunition the obserration of percussion shrnpnel is ensier than that of common shell; when the ground is soft or at long ranges neither percussion sheil is of much use; it should not, therefore, become a liabit to dinge a battery exclusively with percussion shrapnel, since with targets which are visible for but a short time, commou or shrapnel with tine fuzes give a quicker effect. We may indeed ask whether common shell might not, as a rule; be dispensed with in the field, except in peculiar cases, and shrapmel be thus employed for almost all purposes. This would allow us to give yet more attention to the different ways of minging a battery with shrnpnel. There wonld, moreover, then be no necessity to give the order for a change of projectile, which necessity is at present the cause that the Oflicer directing the fire is preoccupied, and that the "shrnpnel-pauses," which can rarely be avoided, constantly take place. If only one kind of projectile were used, it would give ietter results than the two we now hare; while the conduct of fire would be facilitated, and would be simpler, if only for the reason that it would not be necessary to court the rounds as they were fired.

It is again a question whether the corrections ordered for successive guns should be calculated from the last correction given or from the original elevation. Mistakes are noore likely to occur if the correction be continuous, both on account of the elevating gear, and of errors which may be made; as soon as the system of firing by rounds throughout the battery' is given up, there is no reason why the correction should not be given from the original elevation; it is quite as quick and much more easy for the olserver.

With respect to the use of guns at long ranges, the difference in the effect obtained is not a consequence of any failing in the material, which is quite sufficiently good. The reason why long-range fire is considered uudesirable is on account of the difficulty of observation and of laying, when the atimosphere is at all misty or there is inuch smoke. A comparison of the results agninst the sime targets, as follow :

Targets 12 and 16 at 1,000 yards, with 50 at 2,620 yards.

Target 59 at 2,020 against 22 at 2,300 jards.

Target 60 at 1,800 with $2+1$ at 2,400 .

Target 27 at 1,560 with 58 at 2,900 and 3,060 yards, show that we can get good results at long ranges; but Targets 52 and 57 show also that there is a limit to this in practice.

Good effect should always be produced at ringes under 2,200 yards, and withiu this distance any visible or known target ought to be destroyed with certainty.

A quite sufficient effect mas, in case of necessity, be expected up to 2,020 (see Targets 33, 35, 42, 45, 56); if the view be good, the service of the gun quiet, and the observation correct, this may be extended to 3,050 ; as regards ranges beyond this, many chances may intervene: in peace ammunition ${ }^{-}$is too costly for such practice, in war it can too seldom be spared; sce Targets $51,52,57$, and 63 .

The foregoing paper offers no final proof of the opinions giren in it, as it is

I "Lagenwcipe;" fring by complete round, all the gune baring the same eleration. $-N$. L. W. 
not suficiently complete to show entircly convincing results; it is but a beginning and a finger-post, to point out where certainty cau be obtained, though it offers welcome material for this. 'The effect of artillery lies only in their sluooting; it is therefore the only right way to consider all tactical formations from the point of view of fire-efiect, judging them with reference to their good and bad influence on the shooting.

\section{Supploment.}

Further conclusions with regard to practice against recognized tactical formations may be derived from the following record, which forms a supplement to the tactical results of the course of practice for field artillery of 1690.

Practice of the 2 nd Septemler. At Thun.-A battery of $G$ guns in position is fired on and is silenced (I). After a time a section of cavalry on reconnaissance shows itself (2); while these are under fire, some iufantry appear, and are fired on as they extend, first the main body $(3 a)$, then the closed bodies of the first line ( $3 b)$, and, lastly, the groups of skirmishers $(3 c)$.

1. 6 guns with detachments, at 16 yards interval, with the limbers 11 yards in rear of each gun, teams facing the rear. Range, 2,400 yards. 18 common and 18 shrapnel. 'Tine, 15 minutes; interval betreen rounds, 25 seconds; battery ranged on No. 4 gun; distribution of fire, by sections after the small bracket liad been found, by guns when shrapuel fire commenced.

Rcsults.

\begin{tabular}{l|c|c|c|c|c|c|c}
\hline & 1 gun. & 2 gun. & 3 gun. & 4 gun. & 5 gun. & 6 gun. & Total. \\
\hline Iimbers ....... & 24 & 52 & 51 & 42 & 10 & 166 & $\begin{array}{r}3.45 \\
15\end{array}$ \\
Guns........ & 15 & 39 & 16 & 53 & 9 & 10 & 172 \\
\hline Total ........... & 39 & 91 & 67 & 95 & 19 & 206 & 517 \\
\hline
\end{tabular}

07 per cent. of the hits on the limbers, 33 per cent. on the gius.

Mean burst of common, 16 yards orer.

Ditto of shrapnel, 55 yards sbort, 10 feet above plane.

87 dummies hit uut of 96 .

2. 24 cavalry dummies in swarm, half on a slope, the leading half under cover on level ground. Range, 2,460 yards 10 common shell. Time, 3 minutes 30 seconds; interval between rounds, 21 seconds. 58 hits on 21 dummies.

Mean burst of common, 11 yards over.

3a. 3 companies of infantry in line of columns ; each company in column of sections : each section two ranks of standing infantry dummies, and each 40 men; distance of rear ranks, 4 yards; interral between sections, 22 yards ; 240 dummies. Ihange, 1,640 yards. 8 common and 14 shrapnel. Time, 9 minutes 30 scconds; interval betreen zounds, 26 seconds. Battery ranged on the centre company, and fire distributed when the small bracket had been found.

3b. 220 jards in front of Target $3 a$, No. 4 company with 3 sections at 4 yards distance; each section of 20 dumnies in close order, kneeling and half under corer. Range, 1,420 yards. 13 shrapnel. Time, 5 minutes 45 seconds ; interval between rounds, 26 seconds. 
3c. 220 yards in front of Target $3 b$, the 4 th section of No. 4 complany, extended in 4 groups, ench group of 10 kneeling dummies and 13 to 16 yards wide; in rear of each group an Officer standing; total breadth of the 4 groups about 66 jards. Ilange, 1,200 jards. 15 shrapnel. Time, 3 minutes 50 seconds; interval between rounds, 16 seconds. Fire distributed from the first.

Menn burst of shrapnel, Target $3 a, 83$ yards short, 10 feet abore plane.

Dit to Target 3b, 107 yards short, 13 feet above plaue.

Ditto Target $3 c, 137$ yards short, $11 \%$ feet abore plane.

Of 210 dummies in Target $3 a, 213$ hit.

Of 60 ditto, Target $3 b$, 59 hit.

of -15 ditto, Target $3 c, 42$ hit.

The light was good throughout.

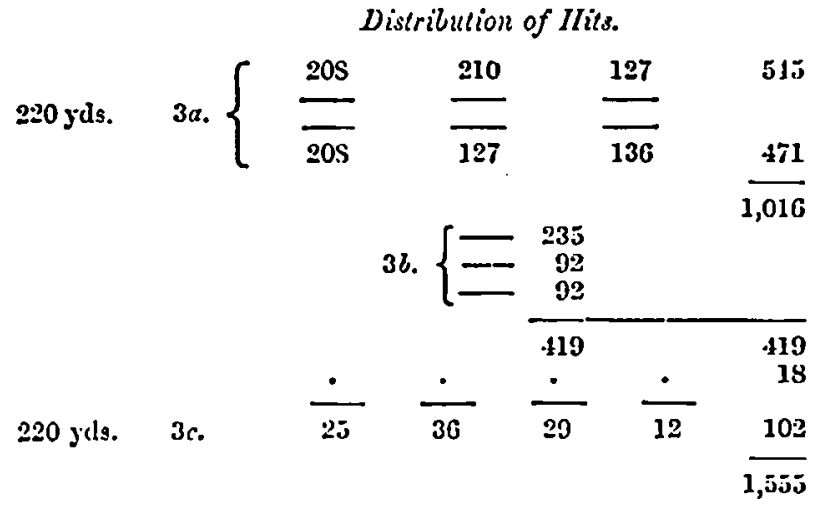

Of the 1,555 hits the reserve, which contained three-fourths of the dunumies (standing), received 65 per cent., the supports 27 per cent., and the groups 8 per cent.

If, in order to compare these results with those obtained in March (given in the former part), we calculate the danger of the several formations in the sime manner, but, eliminating only the first 6 rounds of the enitire 50 (since the fire was directed on the one battalion), we find- 


\begin{tabular}{|c|c|c|c|}
\hline 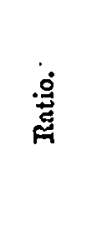 & 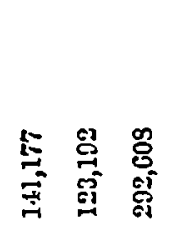 & 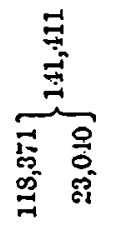 & 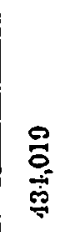 \\
\hline 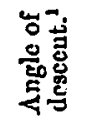 & 苂 寻 & 23 옥 & $:$ \\
\hline 总兽 & 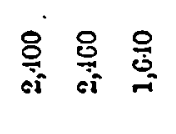 & 疍 & : \\
\hline 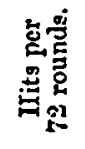 & 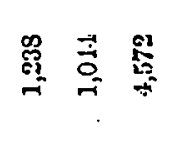 & 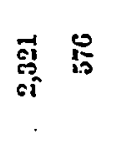 & $\stackrel{\varnothing}{:}$ \\
\hline 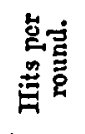 & 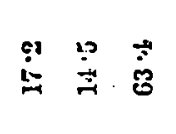 & $\begin{array}{ll}\ddot{c} & P \\
\dot{g} & \dot{m}\end{array}$ & ${ }_{i n}^{2}$ \\
\hline 苚兽 & 司吕兽 & $\stackrel{乛}{乛}$ & $\frac{13}{25}$ \\
\hline 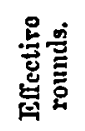 & 尺) $\doteqdot$ & $\cong 2$ & 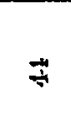 \\
\hline 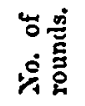 & $\mathscr{e}$ 尺 & 9 & 옥 \\
\hline 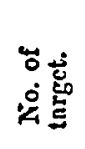 & $\rightarrow$ al & $\ddot{\oplus} \ddot{~}$ & 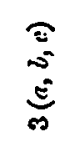 \\
\hline
\end{tabular}


If we compare first the result on Tareget No. I with that given in the table on 1.178 , it falls between the ratios of Targets Nos. 31 and 36, which were in the same formation; we may, therefore, conclude that our method of calculation of effect gives fairly useful and approximate results.

'The proportion of hits on guns and limber's respectively corresponds also to the results on 'Target No.31 (p. 149), and we may thus consider the approximate proportion of from 30 to 40 per cent. of the hits on the guns and from 60 to 70 per cent. on the limbers and teams as constant.

If we compare the fire on cavalry, we find that the ratio of Target No. 2 lies between Target No. 42, the half-column and Target No. 63, the column of sections ( $p .157)$, a position which, considering the fairly considerible depth (22 yards) of the swarms, and the relative closeness of the fornations, appears to be probibly" correct.

The greatest interest is attached to the comparison of Target No. 3 with the tables referring to infantry targets. Taking, first, the whole battalion, the total is in excess of any in Table $I$ (p. 159). This excess is to be ascribed to the fact that the formation given to the target has a considerable depth in the centre and is also relatively close. Of the 1,505 hits, 50 per cent. are on the centre, including skirmishers, supports, and the centre reserve company, while the flanks of the reserve received only 44 per cent., and this, although the front half of the centre consisted of hineeling dummies only, while the leading eighth part has considerable intervals. Since the flank reserve companies are in the same line as the centre company, the fire can be easily distributed along that line; it is owing to this circumstance that, as lias alrendy been shown, the line of columns is the most dangerous formation. The depth of the sections, though only 1 yards, is suflicient to make them a very unfavourable target, as was also evident in the case of the closed double line of 'Target No. 32, where the distance was only 1 yard. From this practice we maj also draw the conclusion, that in all cases where infantry stand in line, and the fire of artillery can thus be easily distributed along it, the depth of the formation should be as small as possible, as soon as the troops are halted; when they are moving, in which case the risk will always be less, the distance between ranks or lines nust be a minimum.

If the ratio of effect on Targets Nos. $3 b$ and $3 c$ be compared to those in Table II (p. 162), we shall find that it falls between Target No. 45, the columu of fours of the company, and Target No. 60, two separnte subdivisions in columns of sections, and thus above those company targets in which at most two sections were held in reserve, and in which the reserve and the supports were not on the same line. Whilst in Targets Nos. 55 and 56 of the above 38 per cent. of hits fall on the two reserve sections, 39 per cent. on the section in support, and 23 per cent. on the shirmishers, in Targets Nos. $3 b$ and $3 c$ we find 78 per cent. on the 3 supporting sections, and 22 per cent. on the skirmishers; this result is derived solely from the depth and closeness of the formation of those supports, and confirms the conclusions which have been already stated with reward to the progressive increase of dauger with each increase of depth of formation.

Target No. 3c, taken alone, may be compared with Table III (p. 16:1), and falls, if unultiplied by 25 (giving 57,600 ), between Targets Nos. 5f and 38 ; this good eftect may be ascribed to the circumstance that the four groups formed distinctly separate targets, on which the distribution of fire was easy and exact.

It would be very advantageous if, during the service practice at the schools of iustruction, and especially during the advanced. course, other formations could be submitted to actual trial under artillery fire; theoretical formations would then prove their efficiency or the reverse, after having been literally "tried in the fire." 